\title{
Introduction to special issue: knowledge, virtue and action-eastern and western perspectives
}

\section{J. Adam Carter ${ }^{1} \cdot{\text { Chienkuo } \mathrm{Mi}^{1} \cdot \text { S. Orestis Palermos }}^{1}$. Duncan Pritchard ${ }^{1}$}

Published online: 12 May 2020

(c) Springer Nature B.V. 2020

The relationship between knowledge, virtue and action is a topic of central interest in mainstream epistemology, and increasingly so over the past decade. ${ }^{1}$ These topics have also occupied an important place in Eastern thought, though Eastern and Western scholarship on this topic - and, more generally, scholarship in epistemology — has traditionally occurred in isolation from one another. This special issue marks an attempt to bring together cutting-edge Western and Eastern thinking on this important epistemological theme which lies at the intersection of both traditions.

The papers included in this special issue, 'Knowledge, Action and Virtue: Eastern and Western Perspectives', represent some of the best work from the inaugural (2015) 'East-West Philosophy Forum' at Soochow University in Taipei, the first annual coming together of philosophers at institutions along an East-West axis, starting from Japan, passing through South Korea, Taiwan, Hong Kong, and Singapore, and ending in Edinburgh. The special issue is not only 'East-West' because of the geographical locations of the institutions of the participating academics, it is also East-West because the content aims at bridging Eastern and Western epistemology, through a focus on shared themes.

The special issue begins with Mi and Ryan's (2016) 'Skilful Reflection as a Master Virtue' which combines insights on virtue and knowledge from Confucian philosophy, dual process theory, and competence-based virtue epistemology. According to $\mathrm{Mi}$ and Ryan, skilful reflection is best understood as a 'master virtue' in the sense that skilful reflection shapes and corrects the other epistemic and intellectual virtues. After defending this idea in some detail, Mi and Ryan put it to work in the service of

\footnotetext{
1 For connections between knowledge and virtue, see, e.g., Sosa (1980, 1991, 2015), Zagzebski (1996), Greco (2009, 2010, 2012), Pritchard (2005, 2012, 2016), Pritchard, Millar and Haddock (2010), Palermos (2014, 2015a, b, 2016), Mi (2015), Carter (2016, 2018, 2020), and Mi and Ryan (2018), Ryan and Mi (2018). For connections between knowledge and action specifically, see Hawthorne (2004), Hawthorne and Stanley (2008), Bengson and Moffet (2011), Carter and Pritchard (2015a, b), Kelp and Simion (2017), and Carter and Poston (2018).
}

\footnotetext{
$凶$ J. Adam Carter

Adam.Carter@glasgow.ac.uk

1 Glasgow, UK
} 
diagnosing some contemporary contested points about how knowledge interfaces with sensitivity and safety.

In 'Situationism, Virtue Epistemology, and Self-Determination Theory', Iizuka (2018) brings a new twist to the 'epistemic situationist' critique of virtue epistemology (e.g., Alfano 2012). The canonical form of this critique-which parallels the situationist critique of virtue ethics (Harman 1999; Doris 2002) —maintains, first, that empirical psychology shows that our beliefs and judgments are influenced to a surprising extent by epistemically irrelevant situational factors; and, second, that this fact, suitably appreciated, is at odds with the virtue epistemologist's claim that crosssituationally consistent intellectual virtues play a prominent role in explaining how we form beliefs and acquire knowledge. Iizuka's key move is to resist this empiricallydriven challenge to virtue epistemology, by drawing attention to additional empirical results that indicate that virtuous motivations are causally efficacious in ways that favour the virtue epistemologist over the situationist.

Chuang (2017), in her paper 'Rational Devotion and Human Perfection', combines insights from the Bhagavad-Gita and Spinoza's Ethics in order to develop a re-interpretation of moksha-viz., the Hindu concept of enlightenment, or human perfection. In the Bhagavad-Gita, Krishna lays out three paths of yoga as the means to achieve human perfection: the path of self-less action (karma yoga), the path of knowledge (jnana yoga), and the path of devotion (bhakti yoga). By investigating the concept of human perfection in Gita and Spinoza, it is the path of devotion, rather than the path of knowledge or action, that is the last step leading to moksha. Central to Chuang's proposal is an appreciation of the intellectual as well as emotive component of devotion.

Finally, in 'Scepticism, Closure and Rationally Grounded Knowledge: A New Solution', Wang (2017) develops a new response to a traditional epistemological puzzle to do with knowledge and skepticism, one that is motivated by the closure principle (e.g., Pritchard 2005, part one, 2015, part one; Hawthorne 2013) which says (roughly) that if one knows that $\mathrm{P}$ and one can competently deduce $\mathrm{Q}$ from $\mathrm{P}$, then one is in a position to know that $\mathrm{Q}$. Wang argues that we can resist the argument from this principle to the skeptical conclusion - at least, as concerns our rationally grounded knowledge—by combining insights from Wittgenstein (1969) and Davidson (1982, 2013).

We believe that these four contributions-each representative in its own way of the special issue's theme-collectively signal the fruitfulness of East/West collaborations, both of philosophers and philosophies, and will serve as a basis for future work at the intersection of these axes.

\section{References}

Alfano, M. (2012). Expanding the situationist challenge to responsibilist virtue epistemology. The Philosophical Quarterly, 62(247), 223-249.

Bengson, J., \& Moffet, M. (2011). Nonpropositional Intellectualism. In J. Bengson \& M. Moffet (Eds.), Knowing how: Essays on knowledge, mind, and action (pp. 161-195). Oxford: Oxford University Press.

Carter, J. A. (2020). De Minimis Normativism: A new theory of full aptness. Philosophical Quarterly. https://doi.org/10.1093/pq/pqaa017. 
Carter, J. A. (2016). Robust virtue epistemology as anti-luck epistemology: A new solution. Pacific Philosophical Quarterly, 97(1), 140-155.

Carter, J. A. (2018). Virtue epistemology, enhancement, and control. Metaphilosophy, 49(3), 283-304.

Carter, J. A., \& Pritchard, D. (2015a). Knowledge-how and cognitive achievement. Philosophy and Phenomenological Research, 91(1), 181-199.

Carter, J. A., \& Pritchard, D. (2015b). Knowledge-how and epistemic luck. Noûs, 49(3), 440-453.

Carter, J. A., \& Poston, T. (2018). A critical introduction to knowledge-how. London: Bloomsbury Publishing.

Chuang, C. (2017). Rational devotion and human perfection. Synthese, 1-23.

Davidson, D. (1982). Rational animals. Dialectica, 36(4), 317-327.

Davidson, D. (2013). On the very idea of a conceptual scheme. The American Philosophical Association Centennial Series, 47, 209-222.

Doris, J. M. (2002). Lack of character: Personality and moral behavior. Cambridge: Cambridge University Press.

Greco, J. (2009). Knowledge as success from ability. Philosophical Studies, 142, 17-26.

Greco, J. (2010). Achieving knowledge. Cambridge: Cambridge University Press.

Greco, J. (2012). Virtues in epistemology. In P. Moser (Ed.), Oxford handbook of epistemology. New York: Oxford University Press.

Harman, G. (1999). Moral philosophy meets social psychology: virtue ethics and the fundamental attribution error. In Proceedings of the Aristotelian Society (pp. 315-331). JSTOR.

Hawthorne, J. (2004). Knowledge and lotteries. Oxford: Oxford University Press.

Hawthorne, J. (2013). The case for closure. In J. Turri, E. Sosa, \& M. Steup (Eds.), Contemporary debates in epistemology (2nd ed., pp. 40-55). Oxford: Blackwell.

Hawthorne, J., \& Stanley, J. (2008). Knowledge and action. Journal of Philosophy, 105(10), 571-590.

lizuka, R. (2018). Situationism, virtue epistemology, and self-determination theory. Synthese, 1-24.

Kelp, C., \& Simion, M. (2017). Criticism and blame in action and assertion. The Journal of Philosophy, $114(2), 76-93$.

Mi, C. (2015). What is knowledge? When confucius meets Ernest Sosa. Dao: A Journal of Comparative Philosophy, 14(3), 355-367. https://doi.org/10.1007/s11712-015-9447-9.

Mi, C., \& Ryan, S. (2016). Skilful reflection as a master virtue. Synthese. https://doi.org/10.1007/s11229016-1192-z.

Mi, C., \& Ryan, S. (2018). Reflective knowledge: Knowledge extended. In J. A. Carter, A. Clark, J. Kallestrup, S. O. Palermos, \& D. Pritchard (Eds.), Extended epistemology, pp. 162-176.

Palermos, S. O. (2014). Knowledge and cognitive integration. Synthese, 191(8), 1931-1951.

Palermos, S. O. (2015a). Active externalism, virtue reliabilism and scientific knowledge. Synthese, 192(9), 2955-2986. https://doi.org/10.1007/s11229-015-0695-3.

Palermos, S. O. (2015b). Could reliability naturally imply safety? European Journal of Philosophy, 23(4), 1192-1208. https://doi.org/10.1111/ejop.12046.

Palermos, S. O. (2016). Spreading the credit: Virtue Reliabilism and weak epistemic anti-individualism. Erkenntnis, 81(2), 305-334. https://doi.org/10.1007/s10670-015-9741-2.

Pritchard, D. (2005). Epistemic luck. Oxford: Oxford University Press.

Pritchard, D. (2012). Anti-luck virtue epistemology. Journal of Philosophy, 109(3), 247-279.

Pritchard, D. (2015). Epistemic angst: Radical skepticism and the groundlessness of our believing. Princeton, NJ: Princeton University Press.

Pritchard, D. (2016). Epistemic risk. Journal of Philosophy, 113(11), 550-571.

Pritchard, D., Millar, A., \& Haddock, A. (2010). The nature and value of knowledge: Three investigations. Oxford: Oxford University Press.

Ryan, S., \& Mi, C. (2018). The contribution of confucius to virtue epistemology. In M. Mizumoto, S. Stich, \& E. McCready (Eds.), Epistemology for the rest of the world, pp. 65-76.

Sosa, E. (1980). The raft and the pyramid: Coherence versus foundations in the theory of knowledge. Midwest Studies in Philosophy, 5, 3-25.

Sosa, E. (1991). Knowledge in perspective: Selected essays in epistemology. Cambridge: Cambridge University Press.

Sosa, E. (2015). Judgment and agency. Oxford: Oxford University Press.

Wang, J. (2017). Scepticism, closure and rationally grounded knowledge: A new solution. Synthese, 1-18. Wittgenstein, L. (1969). On certainty. Oxford: Blackwell. 
Zagzebski, L. T. (1996). Virtues of the mind: An inquiry into the nature of virtue and the ethical foundations of knowledge. Cambridge: Cambridge University Press.

Publisher's Note Springer Nature remains neutral with regard to jurisdictional claims in published maps and institutional affiliations. 